\title{
Gigantoproductid brachiopod storm shell beds in the Mississippian of South China: implications for their palaeoenvironmental and palaeogeographical significances
}

\author{
Le YAO ${ }^{1,2^{*}}$, Markus ARETZ ${ }^{3}$, Yue $\mathrm{LI}^{1} \&$ XIANGDONG WANG ${ }^{1}$ \\ ${ }^{1}$ Key Laboratory of Economic Stratigraphy and Paleogeography, Nanjing Institute of Geology and Paleontology, Chinese Academy of \\ Sciences, Nanjing 210008,China; lyao@nigpas.ac.cn,yueli@nigpas.ac.cn,xdwang@nigpas.ac.cn. \\ ${ }^{2}$ University of Chinese Academy of Sciences, Beijing 100049, China. \\ ${ }^{3}$ Université de Toulouse, UPS (OMP), GET, 14 Avenue Edouard Belin, F-31400 Toulouse, France; markus.aretz@get.omp.eu. \\ * corresponding author
}

ABSTRACT. Late Viséan to Serpukhovian (Mississippian, Carboniferous) storm shell beds of Gigantoproductus (Brachiopoda) are documented for the first time in South China. The shell beds are characterized by sharp and erosional base, internal accumulations of amalgamated shells with erosional structure, and parallel lamination and ripple bedding structures in the uppermost part, indicating obvious characteristics of tempestites. In the shell beds, three taphonomic and sedimentologic types have been distinguished, which are: type A: mostly articulated and convex-down shells in wackestone and packstone, which are developed in distal tempestites with weak water energy around the storm wave-base; type B: dominated disarticulated and convex-up shells in packstone that occur between distal and proximal tempestites in medium hydrodynamic force between the storm wave-base and fair-weather wave-base; and type C: highly fragmented shells in grainstone formed in proximal tempestites under strong hydrodynamic energy above the fair-weather wave-base. The occurrences of proximal and distal tempestites suggest that they were formed by winnowing and transporting under storm surges. During the late Viséan to Serpukhovian, the widely distributed storm shell beds in South China reflect that the South China Block was located in hurricane zone between latitude $10^{\circ}$ and $30^{\circ}$ during this time interval, when ice caps formed on the Gondwana continent.

KEYWORDS: brachiopod, tempestite, taphonomy, sedimentology, late Viséan-Serpukhovian, South China.

\section{Introduction}

Storm beds are distinct facies criteria on shelves and ramps, which are generated by storm winds, such as cyclones and hurricanes in tropical latitudes and blizzards in middle and high latitudes (Tucker \& Wright, 1990; Flügel, 2004). Ager (1973) defined storm beds as tempestites that are commonly characterized by sharp and erosional base, internal structures including accumulations of shells, graded and flat bedding and parallel and cross lamination, and ripple bedding and burrowing presented at the top part (Aigner, 1985; Flügel, 2004; Dattilo et al., 2012). Tempestites are abundant and widely distributed in carbonate environments during the Phanerozoic (e.g. Einsele \& Seilacher, 1982; Flügel, 2004). The sedimentary patterns and biotic distributions of tempestites could provide important information in aspects of their depositional process, palaeoenvironment, palaeogeographical location and even stratigraphic comparison (Johnson, 1989; Lehman \& Pope, 1989; Flügel, 2004; Jin et al., 2013).

Storm shell beds, which are one common type of tempestites and featured by accumulation of shells, were documented during the icehouse periods of the late Ordovician (Lehman \& Pope, 1989; Davis, 1999; Jin et al., 2013), early Silurian (Johnson, 1989; Li \& Rong, 2007; Jin, 2008) and early Carboniferous (Jeffery \& Aigner, 1982; Butts, 2005) and during greenhouse climate, as in the middle Ordovician (McFarland et al., 1999), late Permian (Simões \& Kowalewski, 1998), early Triassic (Boyer et al., 2004), late Jurassic (Fürsich, 1982) and late Early Cretaceous (Fürsich \& Kauffman, 1984). Common to all is that their formation is connected to hurricane formation in the tropical belt of the respective timeslice. In storm shell beds, taphonomic characteristics of shells are generally characterized by amalgamation of articulated, disarticulated and fragmented shells with non-directional distribution (Aigner, 1985; Jin et al., 2013), ranging from proximal tempestites with more disarticulated and fragmented shells to distal tempestites with more articulated and less fragmented shells (Johnson, 1989; Lehman \& Pope, 1989). Sedimentologic features of tempestites also vary from proximal tempestites to distal tempestites dominated by grainstone and mudstone respectively, implying different hydrodynamic energy driven by storm surges and water depths (Aigner, 1985; Butts, 2005; Dattilo et al., 2012). In addition, a comprehensive study on the relationships between taphonomy of shell beds and their palaeogeographical locations was conducted in the late Ordovician (Jin et al., 2013). It was found that non-amalgamated shell beds were located in hurricane-free zone within $10^{\circ}$ of the equator because of the weak Coriolis force. Whereas, amalgamated shell beds occurred in hurricane zone between latitude $10^{\circ}$ and $30^{\circ}$ (Jin et al., 2013). Thus, a relatively precise position of a palaeoequator could be proposed when mapping the spatial distributions of non-amalgamated shell beds and storm shell beds. When the temperature gradient between pole and equator should have been similar to those of the Recent, the zones in which most modern hurricanes occur north and south of the equator $\left(10^{\circ}-30^{\circ}\right)$, could be transferred into the deep time.

In South China, storm beds were extensively recorded during the Phanerozoic (Liu et al., 1986; Zhang et al., 1993; Li \& Rong, 2007; Zhang, 2013). However, storm shell beds have been rarely documented and only a few cases were described in the early Silurian (Li \& Rong, 2007). In the Mississippian, brachiopods were globally distributed and one of the dominant benthic fossil groups (Qiao \& Shen, 2014). Especially, a great number of large-sized species, belonging to the genus Gigantoproductus of subfamily Gigantoproductinae, have been recorded during the Viséan-Serpukhovian around the world (Qiao \& Shen, 2015). Besides, Mississippian is the initial stage of the late Palaeozoic glaciation with prominent glacial deposits on the Gondwana continent (Isbell et al., 2003, 2012; Fielding et al., 2008; Yao et al., 2015). They all provide suitable conditions for the development of storm shell beds. However, to date, no storm shell beds have been reported in the Mississippian strata in South China.

In this paper, brachiopod shell beds have been studied in Huishui County of Guizhou Province in the Yashui (YS) $\left(26^{\circ} 00^{\prime} 47.6^{\prime \prime} \mathrm{N}, 106^{\circ} 45^{\prime} 28.0^{\prime \prime} \mathrm{E}\right)$ and Duanshan (DS) $\left(25^{\circ} 50^{\prime} 07.6^{\prime \prime} \mathrm{N}, 106^{\circ} 36^{\prime} 17.9^{\prime \prime} \mathrm{E}\right)$ sections located at about $4 \mathrm{~km}$ north of Yashui town and about $3 \mathrm{~km}$ east of Duanshan town respectively, and in Tianlin County of Guangxi Province in the Gandongzi (GDZ) $\left(24^{\circ} 31^{\prime} 55.2^{\prime \prime} \mathrm{N}, 106^{\circ} 21^{\prime} 36.9^{\prime \prime} \mathrm{E}\right)$ section located at about $1 \mathrm{~km}$ west of Gandongzi village (Fig. 1a, b). The main purposes of this study are (1) to describe taphonomic and sedimentologic characteristics of the shell beds; (2) to interpret mechanism of the shell bed formation; (3) to provide implications of the shell beds for their palaeoenvironmental and palaeogeographical significances.

\section{Geological setting}

\subsection{Palaeogeography}

During Viséan to Serpukhovian times, the South China Block (SCB) was located in the Southern Hemisphere near the equator in the northeastern Palaeotethys. It consists of Yangtze and Cathaysia Old Lands (Fig. 1c). Between these two topographical emerged highs, the marine facies realm is highly differentiated 


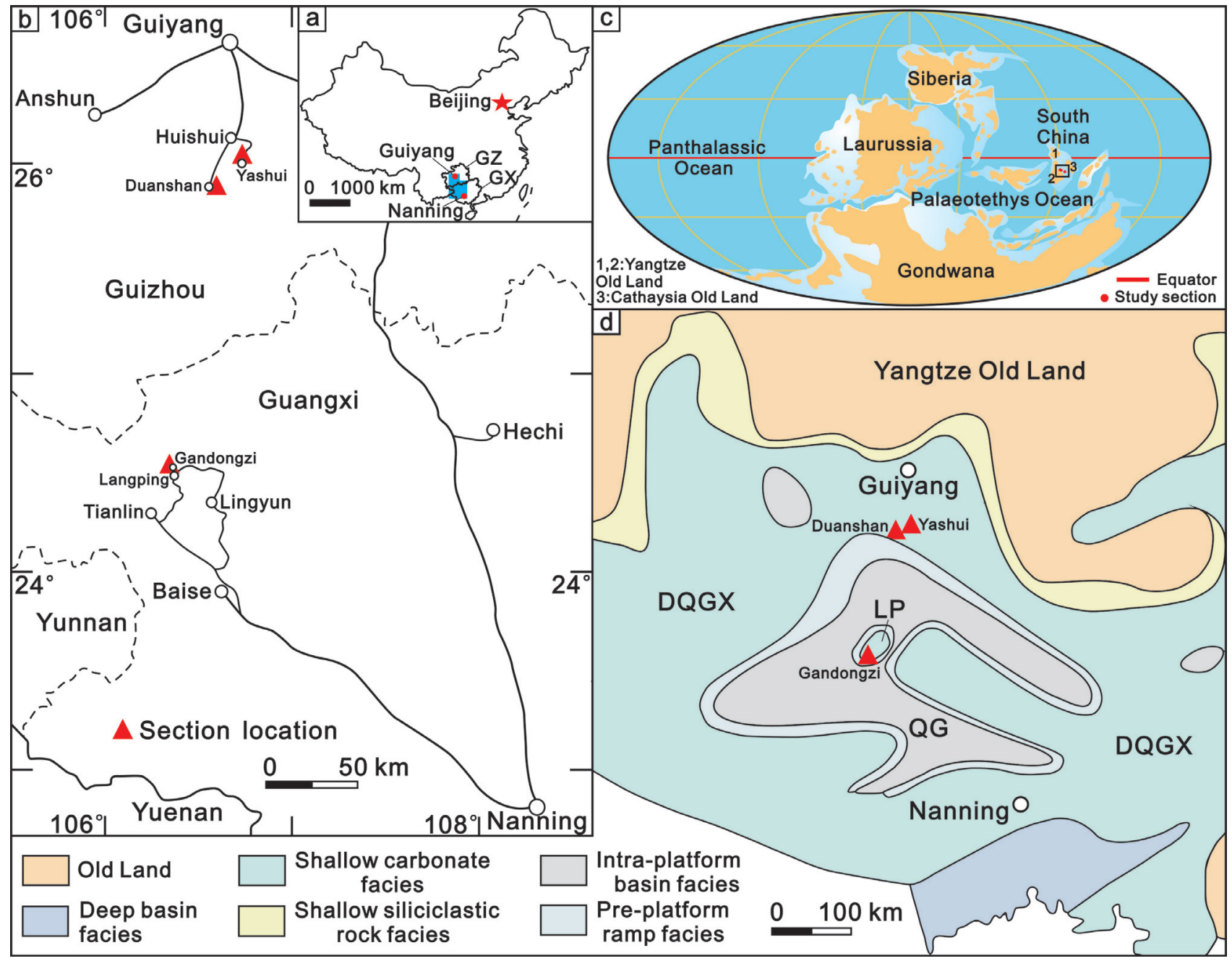

Figure 1. (a) Location of Guizhou and Guangxi provinces, and their capital cities in China. GZ: Guizhou Province, GX: Guangxi Province. (b) Location of the studied sections, the map of Fig. 1 (b) is the amplification of the shadow area of Fig. 1 (a). (c) Global palaeogeography map for the middle-late Mississippian (340 Ma) (after Blakey, 2011). The black rectangle represents the Fig. 1 (d); note that the South China craton was rotated $\sim 90^{\circ}$ counterclockwise relative to its modern orientation. (d) The Viséan-Serpukhovian palaeogeography of the South China Block (after Feng et al., 1998) and location of the studied sections. DQGX: Dian-Qian-Gui-Xiang platform, LP: Langping isolated platform, QG: Qian-Gui basin.

(Fig. 1d) (Feng et al., 1998). Narrow nearshore siliciclastic belts border the southern Yangtze and western Cathaysia Old Lands. Most parts of the SCB are covered by shallow water carbonates of the Dian-Qian-Gui-Xiang carbonate platform. This platform is dissected by several basins and the largest one, the Qian-Gui basin includes the isolated Langping carbonate platform. The basins are NE-SW and NW-SE trending rifts and lithologically dominated by black shales, thin-bedded limestones and siliceous rocks (Jiao et al., 2003). Deep-basin facies are located in the eastern part of the SCB (southern in present day) (Fig. 1c, d) (Feng et al., 1998). In this study, the Yashui and Duanshan sections, and the Gandongzi section are located on the margins of the Dian-QianGui-Xiang platform and Langping platform, respectively (Fig. 1d).

\subsection{Lithostratigraphy}

Correlations of Mississippian strata in South China were summarized by Wang \& Jin (2000), Hance et al. (2011) and Wang et al. (2013). In the upper Viséan to Serpukhovian, the Shangsi and Baizuo formations are separated in the Huishui area, whereas the Du'an Formation comprises the entire interval in Tianlin area (Hance et al., 2011; Wang et al., 2013). In the Yashui section, the upper Shangsi Formation (30 m thick) consists of lightgrey to dark-grey, middle- to thick-bedded (c. 0.2 to c. $1.0 \mathrm{~m}$ ) mudstone, wackestone and packstone interbedded with shale, nodular limestone and dolomitic limestone, yielding abundant corals and brachiopods (Lin et al., 2012). One distinct palaeokarst surface occurs at the top of this formation. The Baizuo Formation
(88 $\mathrm{m}$ thick) contains light-grey to dark-grey, medium- to thickbedded wackestone, packstone and grainstone intercalated with shale, muddy limestone, dolomitic limestone and breccia rich in brachiopod and coral faunas (Lin et al., 2012) (Fig. 2). The shale deposits in Yashui section result from carbonate dissolution (karstification) and siliciclastic sediment input, which implies a very shallow water (Chen et al., 2016). According to Groves et al. (2012) "pervasive lime mud, calcispheres, and a variety of skeletal calcareous algae suggest a relatively quiet setting within the euphotic zone". In the Duanshan section, the Shangsi Formation (30 m thick) is mainly composed of dark-grey thickbedded $(\mathrm{c} .1 .0 \mathrm{~m})$ wackestone and packstone including abundant brachiopods and corals. The absence of shallow-water shale deposits, dolomitic limestone and palaeokarst surface from this section indicates a relatively deeper shallow marine environment, compared with the Yashui section (Fig. 2). In the Gandongzi section, the Du'an Formation (60 m thick) contains light-grey to dark-grey thick massive packstone and grainstone interbedded with mudstone and wackestone. They are rich in brachiopods, crinoids and oncolites, implying a shallow marine turbulent environment (Fang \& Hou, 1986) (Fig. 2).

Brachiopod shell beds have been studied from the upper Shangsi and Baizuo formations in the Yashui section, the Shangsi Formation in the Duanshan section and the Du'an Formation in the Gandongzi section (Fig. 2). The taxonomic composition of the brachiopods in the shell beds is dominated by one genus (Gigantoproductus), which is identified based on their characteristics of large shells with large width (adult individual 
usually more than $10 \mathrm{~cm}$ wide), strong curved trail and shell line, small body cavity and concave-convex shell type (Prentice, 1950) (Fig. 3a, b). At the Yashui section, two Gigantoproductus shell beds ( $\mathrm{YSB}_{1}$ in the lower part and $\mathrm{YSB}_{2}$ in the upper part) are developed in the Shangsi Formation and Baizuo Formation with thin thicknesses of $0.3 \mathrm{~m}$ and $0.5 \mathrm{~m}$, respectively (Fig. 2). Most Gigantoproductus shells are concordant (disarticulated and convex-up) with loosely packed in the $\mathrm{YSB}_{2}$ (Fig. 3c). Two Gigantoproductus shell beds (DSB in the lower part and $\mathrm{DSB}_{2}$ in the upper part) are present in the Shangsi Formation in the Duanshan section and their thicknesses are medium and vary from $1 \mathrm{~m}$ to $1.5 \mathrm{~m}$ (Fig. 2). Gigantoproductus shells are majorly concordant (disarticulated and convex-up) and densely packed, with coral fragments horizontally preserved in the DSB (Fig. $_{1}$ $3 \mathrm{~b}, \mathrm{~d})$. At the Gandongzi section, four Gigantoproductus shell beds have been recognized in the Du'an Formation (Fig. 2). At the base of the Gandongzi section, a Gigantoproductus shell bed $\left(\mathrm{GSB}_{1}\right.$ ) is very thick (about $13 \mathrm{~m}$ ) with vertical changes of the Gigantoproductus shell abundances. These are concordant dominated by articulation and convex-down (Fig. 3e). The other three shell beds $\left(\mathrm{GSB}_{2}, \mathrm{GSB}_{3}\right.$ and $\left.\mathrm{GSB}_{4}\right)$ of the upper Gandongzi section are medium in thickness of $0.5 \mathrm{~m}$ to $2 \mathrm{~m}$, comprising highbreakage and densely packed Gigantoproductus shells (Fig. 3f).

\subsection{Biostratigraphy}

A rough age determination is due to the stratigraphic distribution of the genus Gigantoproductus from the middle Viséan to the Serpukhovian (Qiao \& Shen, 2015). Carbonate microfossils, especially foraminifers indicate more precise ages. In the Yashui section, Wang (2011) and Groves et al. (2012) conducted highprecision foraminifer biostratigraphy. The lower part of the Yashui section yields abundant typical late Viséan foraminifers such as Eostaffella, Endothyra, Archaediscus, Earlandia, Pseudoendothyra and Endothyranopsis, and is equivalent to the MFZ15 foraminiferal Zone in Europe (Poty et al., 2006). The Viséan-Serpukhovian boundary is determined at $49 \mathrm{~m}$ based on the lowest occurrence of rare "tortula-like" specimens, a potential Serpukhovian marker (Groves et al., 2012) (Fig. 2). The foraminifers Biseriella, Zellerinella, Globoendothyra, Globivalvulina and Paraarchaediscus indicate a Serpukhovian age for the upward part (Wang, 2011). In the Duanshan section, the occurrences of the foraminifer assemblage including Endothyranopsis, Eostaffella, Endothyra, Koskinobigenerina and Climacammina, indicate a late Viséan age (Poty et al., 2006; Groves et al., 2012). At the Gandongzi section, the presence of Endothyranopsis, Koskinobegenerina and Climacammina also suggests a late Viséan age (Poty et al., 2006; Groves et al., 2012).

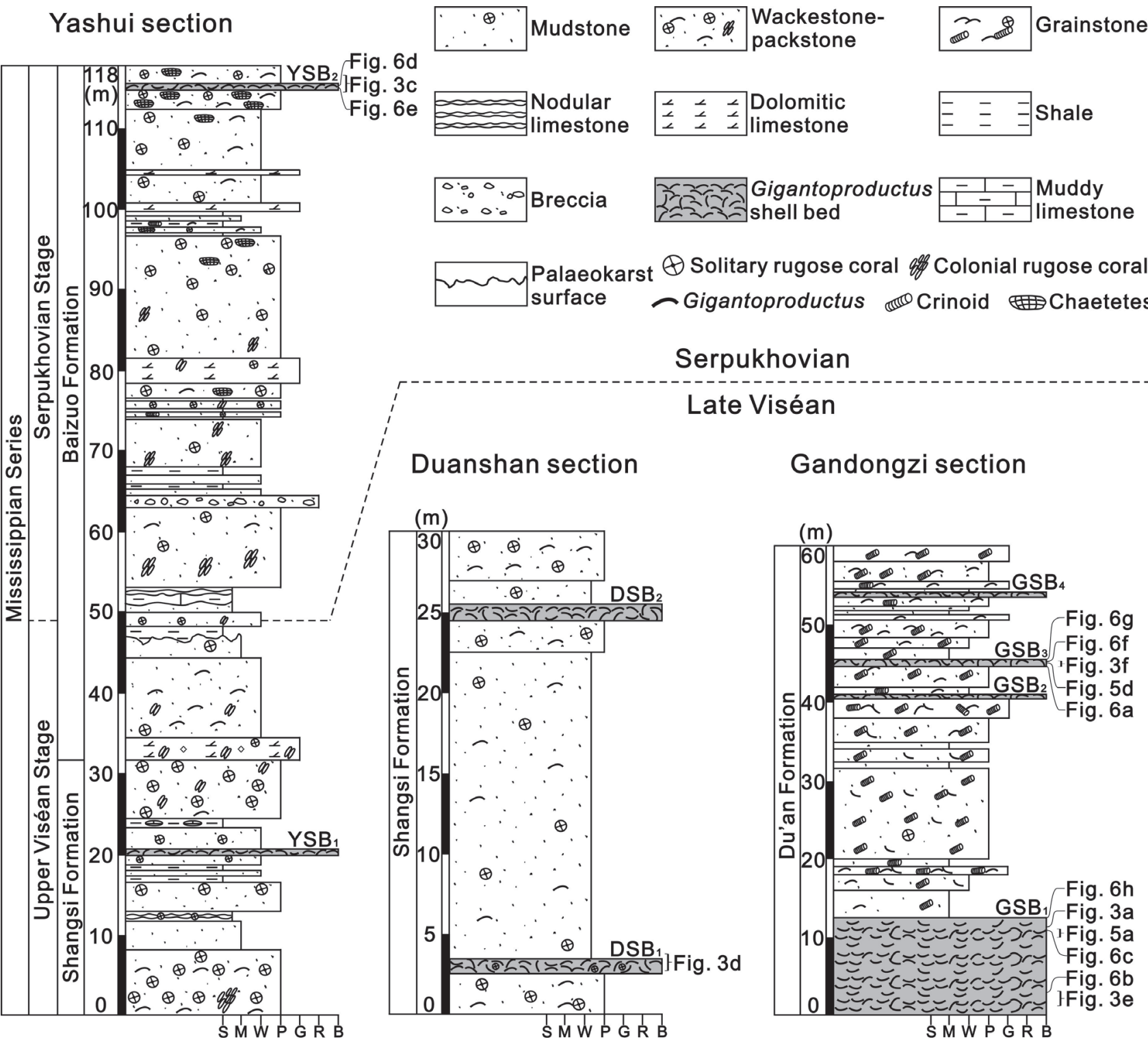

Figure 2. Lithologic columns of the upper Viséan-Serpukhovian strata and location of Gigantoproductus shell beds in the Yashui, Duanshan and Gandongzi sections. S: Shale, M: Muddy limestone/Mudstone, W: Wackestone, P: Packstone, G: Grainstone, R: Rudstone, B: Brachiopod shell bed, DSB: The shell bed in the Duanshan section, GSB: The shell bed in the Gandongzi section, YSB: The shell bed in the Yashui section. 

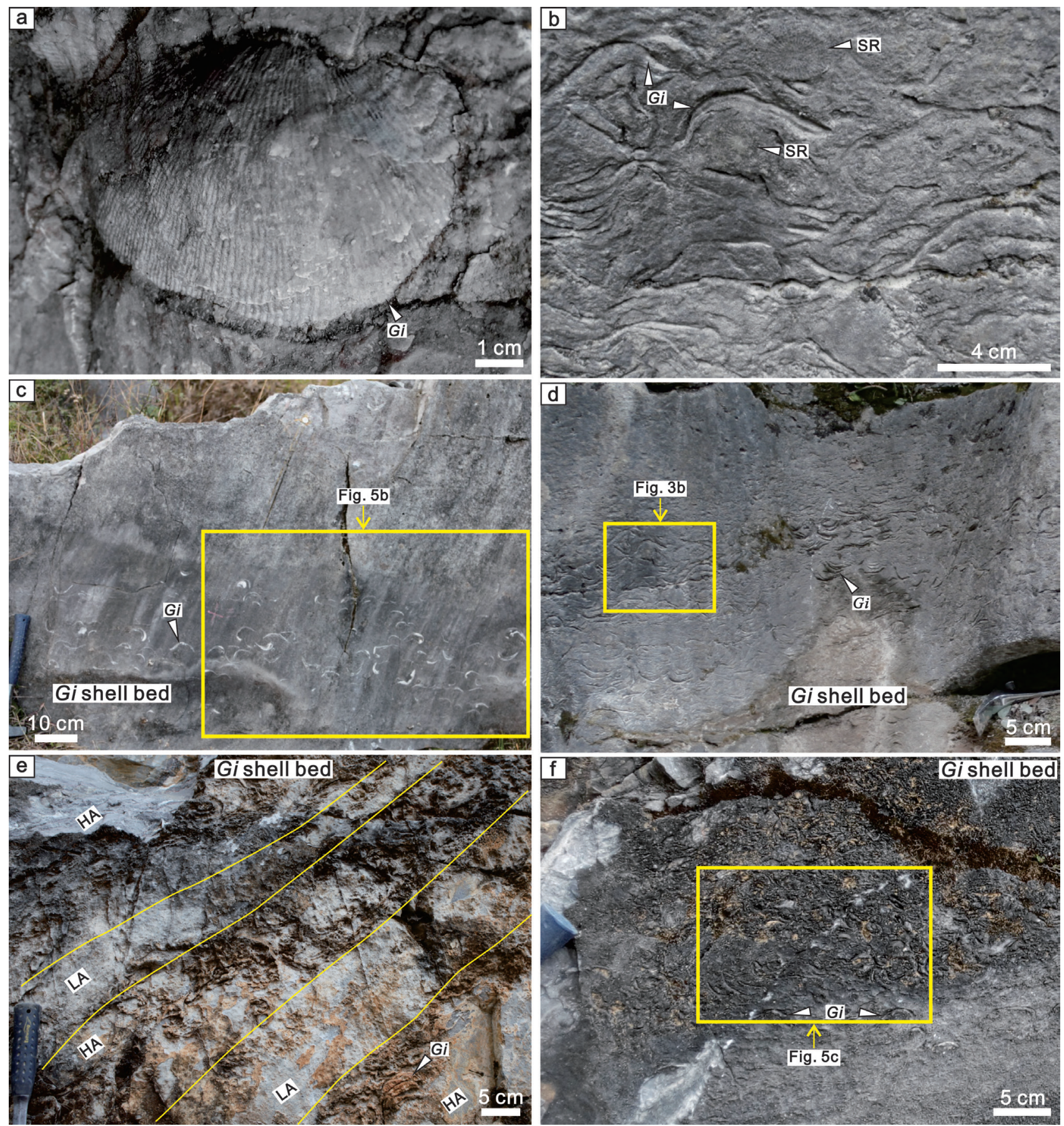

Figure 3. Field photographs of Gigantoproductus and their shell beds. (a) Ventral valve of Gigantoproductus in the shell bed at the base of the Gandongzi section $\left(\mathrm{GSB}_{1}\right)$. Gi: Gigantoproductus. (b) Gigantoproductus and solitary rugose corals in the lower Gigantoproductus shell bed in the Duanshan section (DSB $)_{1}$ ). Gi: Gigantoproductus, SR: Solitary rugose coral. (c) Upper Gigantoproductus shell bed in the Yashui section (YSB $)_{2}$. Gi: Gigantoproductus. (d) Lower Gigantoproductus shell bed in the Duanshan section $\left(\mathrm{DSB}_{1}\right)$, the area of the yellow rectangle is Fig. 3 (b). Gi: Gigantoproductus. (e) Gigantoproductus shell bed at the base of the Gandongzi section $\left(\mathrm{GSB}_{1}\right)$. Gi: Gigantoproductus, HA: High abundance, LA: Low abundance. (f) Gigantoproductus shell bed in the upper part of the Gandongzi section $\left(\mathrm{GSB}_{3}\right)$. Gi: Gigantoproductus.

Thus, the shell beds are late Viséan in age, except the shell bed $\mathrm{YSB}_{2}$, which is Serpukhovian in age.

\section{Materials and methods}

A total of 57 samples were collected from the underlying limestones of Gigantoproductus shell beds to the overlying limestones of the shell beds in the Gandongzi section, and from the shell beds in the Yashui and Duanshan sections. For each sample, at least one orientated thin section was made, and a total of 76 thin sections (about $40 \times 50 \mathrm{~mm}$ sized) are available for microfacies analysis. Description of the shell beds is based on the conceptual framework provided by Kidwell et al. (1986) and Kidwell \& Holland (1991). Quantitative analysis of the contents of disarticulated, articulated, and convex-up and -down shells by counting relevant shells based on a well exposed, relatively flat and smooth surface (about $50 \times 50 \mathrm{~cm}$ sized) was done at the $\mathrm{YSB}_{2}$ and $\mathrm{GSB}_{1}$ following the method of Chen et al. (2013). Identification of microfacies types follows the classification schemes proposed by Dunham (1962) and Embry \& Klovan (1971).

\section{Results}

\subsection{Taphonomy}

Three distinct taphonomic types of Gigantoproductus shells are distinguished in terms of articulation or disarticulation, orientation (convex-up or -down) and fragmentation degree of the shells in the studied shell beds (Fig. 4, Table 1). Type A (TA) 


\begin{tabular}{|c|c|c|c|}
\hline Gigantoproductus shell bed & Type A shell bed $\left(\mathrm{GSB}_{1}\right)$ & Type B shell bed $\left(\mathrm{DSB}_{1}\right.$ and $\left.\mathrm{YSB}_{2}\right)$ & Type $\mathrm{C}$ shell bed $\left(\mathrm{GSB}_{3}\right)$ \\
\hline Shell bed type & Distal tempestites & Distal-proximal tempestites & Proximal tempestites \\
\hline Thickness & Very thick $(13 \mathrm{~m})$ & Thin to medium $(0.3-1.5 \mathrm{~m})$ & Thin to medium $(0.5-2 \mathrm{~m})$ \\
\hline Associated grains & Crinoids and peloids & $\begin{array}{l}\text { Crinoids, foraminifers, corals, } \\
\text { gastropods and peloids }\end{array}$ & $\begin{array}{l}\text { Crinoids, foraminifers, calcareous algae, } \\
\text { oncoids and peloids }\end{array}$ \\
\hline Taphonomy of shells & $\begin{array}{l}\text { Dominant articulated }(52 \%) \text {, } \\
\text { convex-down }(71 \%) \text { shells } \\
\text { with low fragmentation } \\
(9 \%)\end{array}$ & $\begin{array}{l}\text { Dominant disarticulated }(88 \%) \text {, } \\
\text { convex-up }(78 \%) \text { shells with medium } \\
\text { fragmentation }(31 \%)\end{array}$ & High fragmentation $(>60 \%)$ \\
\hline Dunham's classification & $\begin{array}{l}\text { Wackestone, packstone and } \\
\text { mudstone }\end{array}$ & Packstone & Grainstone and mudstone \\
\hline Sedimentary structures & $\begin{array}{l}\text { Parallel lamination and } \\
\text { geopetal structure }\end{array}$ & Erosional surface and geopetal structure & Erosional surface and ripple bedding \\
\hline $\begin{array}{l}\text { Depositional environment } \\
\text { interpretation }\end{array}$ & $\begin{array}{l}\text { Formation around storm } \\
\text { wave-base }\end{array}$ & $\begin{array}{l}\text { Formation between storm wave-base } \\
\text { and fair-weather wave-base }\end{array}$ & Formation above fair-weather wave-base \\
\hline Located section & Basal Gandongzi section & Yashui and Duanshan sections & Upper Gandongzi section \\
\hline
\end{tabular}

Table 1. Comparison of the three taphonomic types of Gigantoproductus shell beds in South China.

is characterized by articulated and convex-down shells with low fragmentation, which is rare and only present in the GSB at the base of the Gandongzi section (Fig. 4a, Table 1). Type B (TB) is featured by disarticulated and convex-up shells with medium fragmentation (Fig. 4b, Table 1), and commonly occurs in the shell beds in the Yashui and Duanshan sections. Type C (TC) is represented by high-breakage shells, and developed in the $\mathrm{GSB}_{2}$, $\mathrm{GSB}_{3}$ and $\mathrm{GSB}_{4}$ in the upper part of the Gandongzi section (Fig. 4c, Table 1). Quantitative analysis of disarticulated, articulated, convex-up and -down and fragmented shells is carried out in the TA and TB shell beds (Fig. 5a, b). It is not done for the TC shell beds due to the almost exclusiveness of highly fragmented shells in these beds (Fig. 5c, d).

\subsubsection{Disarticulated or articulated shells}

In the GSB (TA shell bed), the shells include 44 articulated shells $(52 \%)$ of the 85 counted shells (Fig. 5a, Table 2), which implies a relatively weak hydrodynamic energy (Johnson, 1989; Lehman \& Pope, 1989; Chen et al., 2013). The low proportion of shell fragments (9\%) supports this hypothesis (Table 2). The shells in the $\mathrm{YSB}_{2}$ (TB shell bed) comprise 74 disarticulated shells (88\%) relative to 10 articulated shells (Fig. 5b, Table 2). The high amounts of disarticulated shells indicate a strong hydrodynamic force, driven by storm surges and water currents (Johnson, 1989; Lehman \& Pope, 1989; Chen et al., 2013). The content of shell fragmentation is medium high $(31 \%)$ in the $\mathrm{YSB}_{2}$, compared with the GSB (Table 2).

\subsubsection{Convex-up or -down shells}

Among the 58 convex-up and -down shells examined on the surface of the $\mathrm{GSB}_{1}, 41$ shells $(71 \%)$ are arranged in convex-down orientation with 17 shells (29\%) convex-up (Fig. 5a, Table 2). Taphonomic studies revealed that the shell assemblage dominated by convex-down and -up shells was caused by low and high water a

\section{(Distal tempestite)}

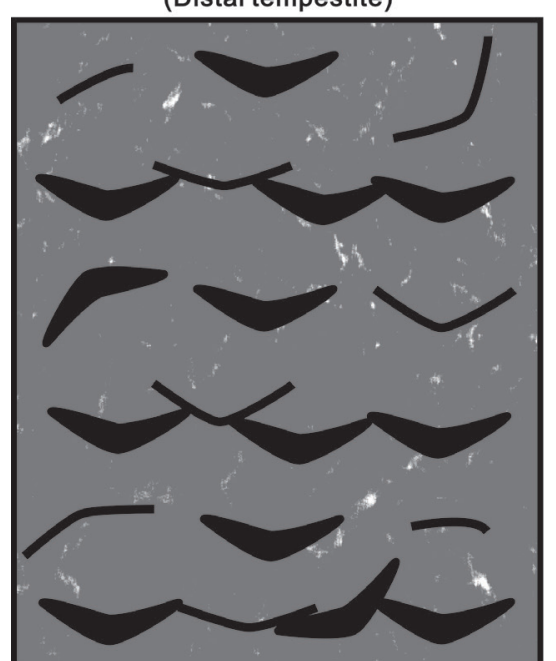

Micrite Disarticulated and convex-down Gigantoproductus shell

\section{Gigantoproductus storm shell bed}

b Type B

(Distal-proximal tempestite)

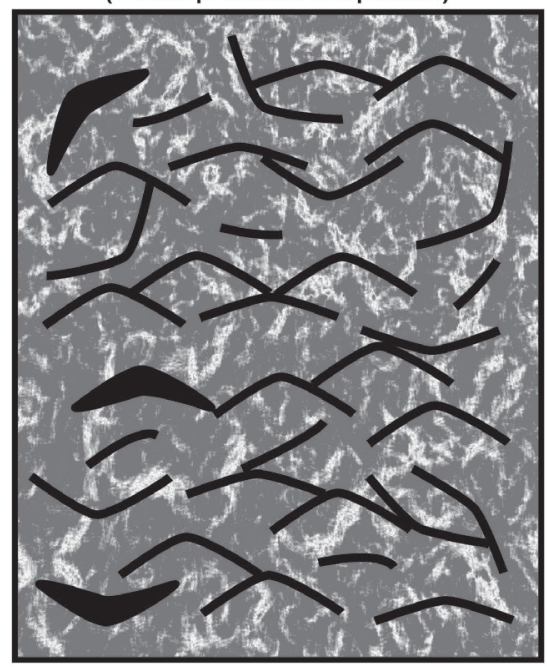

Articulated and convex-down Gigantoproductus shell c (Proximal tempestite)

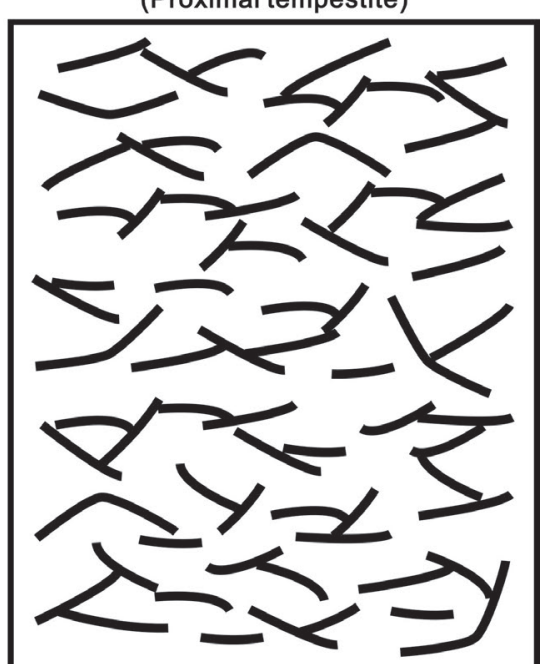

Articulated and convex-up Gigantoproductus shell
Disarticulated and convex-up Gigantoproductus shell

Figure 4. Sketch of taphonomic types and sedimentary characteristics of Gigantoproductus shell beds. Type A is characterized by articulated and convexdown shells with low fragmentation, much micrite and few sparry calcite. Type B is dominated by disarticulated and convex-up shells with medium fragmentation, medium micrite and sparry calcite. Type $\mathrm{C}$ is featured by high-breakage shells, cemented by sparry calcite. 


\begin{tabular}{|c|c|c|c|c|}
\hline Gigantoproductus shell bed & $\begin{array}{l}\text { Total counted } \\
\text { shells (Number) }\end{array}$ & $\begin{array}{l}\text { Disarticulated shells } \\
\text { (Number and percent) }\end{array}$ & $\begin{array}{c}\text { Articulated shells } \\
\text { (Number and percent) }\end{array}$ & $\begin{array}{c}\text { Fragmented shells } \\
\text { (Number and percent) }\end{array}$ \\
\hline Type A shell bed $\left(\mathrm{GSB}_{1}\right)$ & 85 & 41 and $48 \%$ & 44 and $52 \%$ & 8 and $9 \%$ \\
\hline Type B shell bed $\left(\mathrm{YSB}_{2}\right)$ & 84 & 74 and $88 \%$ & 10 and $12 \%$ & 26 and $31 \%$ \\
\hline Gigantoproductus shell bed & $\begin{array}{l}\text { Total convex-up and } \\
\text {-down shells (Number) }\end{array}$ & $\begin{array}{l}\text { Convex-up shells } \\
\text { (Number and percent) }\end{array}$ & $\begin{array}{l}\text { Convex-down shells } \\
\text { (Number and percent) }\end{array}$ & \\
\hline Type A shell bed $\left(\mathrm{GSB}_{1}\right)$ & 58 & 17 and $29 \%$ & 41 and $71 \%$ & \\
\hline Type B shell bed $\left(\mathrm{YSB}_{2}\right)$ & 45 & 35 and $78 \%$ & 10 and $22 \%$ & \\
\hline
\end{tabular}

Table 2. Quantitative data of Gigantoproductus shells from the shell beds in South China.

energy, respectively (Jeffery \& Aigner, 1982; McFarland et al., 1999; Butts, 2005; Chen et al., 2013). Hence, in the GSB, the high contents of shells in convex-down orientation indicate that the shells were affected by low hydrodynamic energy before they were buried (Jeffery \& Aigner, 1982; Butts, 2005). According to the observation of 45 convex shells on the surface of the $\mathrm{YSB}_{2}, 35$ shells (78\%) are convex-up and 10 shells (22\%) are convex-down (Fig. 5b, Table 2).

\subsection{Microfacies characteristics}

From the systematic studies on the microfacies of Gigantoproductus shell beds in the Yashui, Duanshan and Gandongzi sections, sedimentary structures, including sharp and erosional base, erosional surface, parallel and ripple lamination/ bedding and geopetal structures, and microfacies types, containing mudstone, wackestone, packstone and grainstone, are identified (Fig. 6, Table 1).

\subsubsection{Base of the shell bed}

The base of tempestites is generally characterized by a sharp and erosional surface (Flügel, 2004), which is found at the base of the $\mathrm{GSB}_{3}$ in the upper Gandongzi section (Fig. 6a). The underlying bed is a peloidal packstone mainly composed of medium to well sorted peloids. Bioclastic grains include crinoids, which are rare and make up about $5 \%$ of the total components. The spaces between the peloids and bioclasts are filled with micrite and sparry calcite (Fig. 6a). A distinct sharp and erosional boundary is present at the base of the shell bed and characterized by a sparry calcite belt, which suggests high water energy (Yao et al., 2016). This hypothesis was also supported by the highly fragmented shells and rounded and well sorted peloids in the sparry calcite (Fig. 6a). Above this boundary lay grainstones mainly composed of brachiopods, crinoids and peloids cemented by sparry calcite. The brachiopods show high breakage and non-directional distribution, and the peloids are generally well sorted (Fig. 6a).
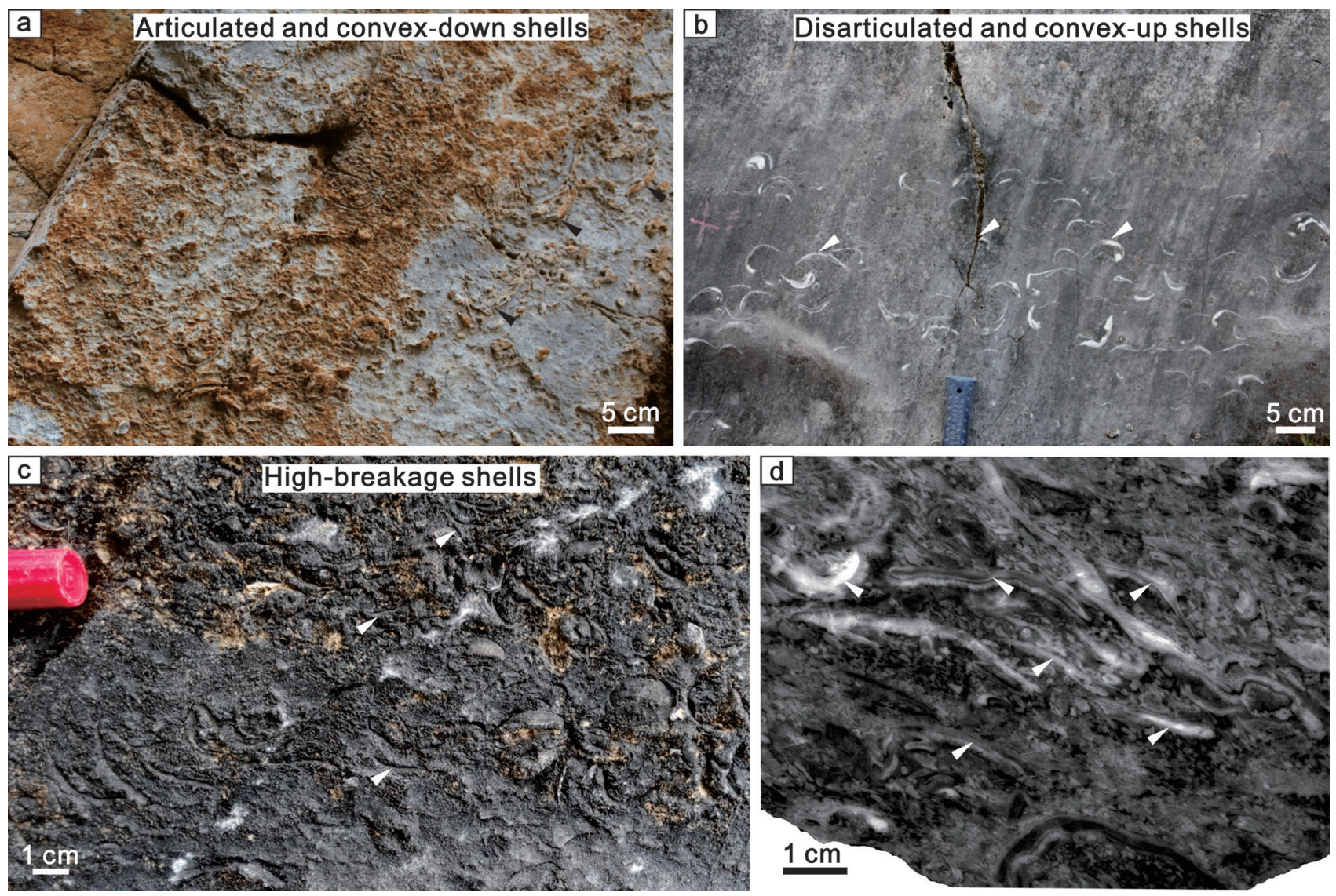

Figure 5. Field photographs and polished slab of three different taphonomic types in Gigantoproductus shell beds. (a) Mostly articulated and convexdown shells (Black triangle) in the shell bed at the base of the Gandongzi section (GSB $)$. (b) is the enlargement of the area of the yellow rectangle in Fig. 3 (c) and displays the dominated disarticulated and convex-up shells (White triangle) in the shell bed in the upper part of the Yashui section (YSB ) . (c) is the amplification of the yellow rectangle area in Fig. 3 (f) and shows the high-breakage shells (White triangle) in the shell bed in the upper part of the Gandongzi section (GSB $)_{3}$. (d) Highly broken shells (White triangle), polished slab in the GSB, Gandongzi section. 

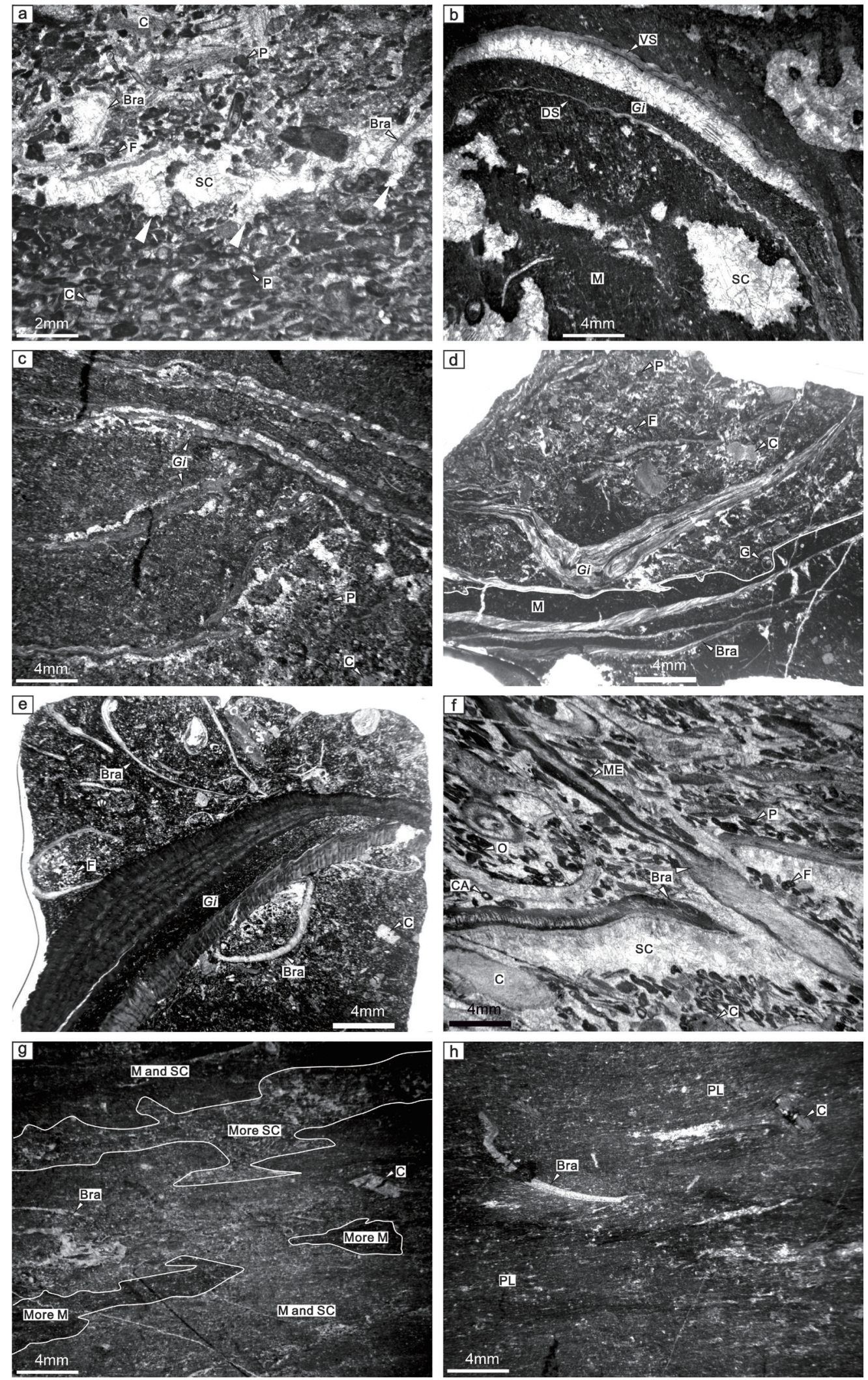

Figure 6. Microfacies types and sedimentary structures in Gigantoproductus shell beds. (a) Sharp and erosional base (White triangle) in Gigantoproductus shell bed in the upper part of the Gandongzi section $\left(\mathrm{GSB}_{3}\right)$. Bra: Brachiopod, C: Crinoid, F: Foraminifer, P: Peloid, SC: Sparry calcite. (b) Wackestone with geopetal structure in Gigantoproductus shell bed at the base of the Gandongzi section (GSB $)$. DS: Dorsal valve, Gi: Gigantoproductus, M: Micrite, SC: Sparry calcite, VS: Ventral valve. (c) Packstone in Gigantoproductus shell bed at the base of the Gandongzi section (GSB $)$. C: Crinoid, Gi: Gigantoproductus, P: Peloid. (d) Packstone with erosional surface (White line) in Gigantoproductus shell bed in the lower part of the Duanshan section $\left(\mathrm{DSB}_{1}\right)$. Bra: Brachiopod, C: Crinoid, F: Foraminifer, G: Gastropod, Gi: Gigantoproductus, M: Micrite, P: Peloid, SC: Sparry calcite. (e) Packstone with geopetal structure in Gigantoproductus shell bed in the upper part of the Yashui section $\left(\mathrm{YSB}_{2}\right)$. Bra: Brachiopod, C: Crinoid, Gi: Gigantoproductus. (f) Grainstone in Gigantoproductus shell bed in the upper part of the Gandongzi section $\left(\mathrm{GSB}_{3}\right)$. Bra: Brachiopod, C: Crinoid, CA: Calcareous algae, F: Foraminifer, ME: Micrite envelope, O: Oncoid, P: Peloid, SC: Sparry calcite. (g) Ripple boundary (White line) between different components in the mudstone at the uppermost part of Gigantoproductus shell bed in the upper part of the Gandongzi section ( $\left.\mathrm{GSB}_{3}\right)$. Bra: Brachiopod, C: Crinoid, M: Micrite, SC: Sparry calcite. (h) Parallel lamination structure in the mudstone at the uppermost part of Gigantoproductus shell bed at the base of Gandongzi section $\left(\mathrm{GSB}_{1}\right)$. Bra: Brachiopod, C: Crinoid, PL: Parallel lamination. 


\subsubsection{Interior of the shell beds}

\section{Type A shell bed}

The microfacies of the GSB consist of wackestone and packstone, which are featured by articulated Gigantoproductus shells (Fig. 6b, c). The shells are the main constitutions with up to $25-35 \%$ and $55-65 \%$ of the total components in wackestone and packstone, respectively. Other grains include crinoids and peloids. Internal spaces between the grains are filled with micrite and with some sparry calcite (Fig. 6b, c). Geopetal structures also occur in some skeletons of the articulated shells (Fig. 6b).

\section{Type $B$ shell bed}

In the $\mathrm{DSB}_{1}$ and $\mathrm{YSB}_{2}$, the microfacies are composed of packstone with abundant reworked Gigantoproductus shells (Fig. 6d, e). The shells are mostly disarticulated comprising $45-55 \%$ of the total components. Besides, crinoids, foraminifers and gastropods also occur around the shells. The spaces between the bioclasts are full of micrite, peloids and sparry calcite (Fig. 6d, e).

Erosional surface as one common structure of tempestites (Flügel, 2004) is recognized in the internal DSB (Fig. 6d). The erosional surface is characterized by irregular boundary between two different constitutions, with dark micrite in the lower part and abundant bioclasts and sparry calcite in the upper part (Fig. 6d). Besides, geopetal structures also occur in the articulated brachiopod shells (Fig. 6e)

\section{Type C shell bed}

The microfacies of $\mathrm{GSB}_{3}$ are comprised of grainstone with abundant highly broken Gigantoproductus shells cemented by sparry calcite (Fig. 6f). The shells are in contact with each other and sometimes coated by micrite, taking account for $50-60 \%$ of the total components. Other grains include crinoids, foraminifers, calcareous algae, peloids and oncoids (Fig. 6f).

\subsubsection{Top of the shell beds}

The microfacies in the top part of the shell beds are characterized by micritic carbonates with few bioclasts (mudstone texture), and are present at the uppermost parts of the $\mathrm{GSB}_{1}$ and $\mathrm{GSB}_{3}$ (Fig. $6 \mathrm{~g}$, h). Bioclasts contain brachiopods and crinoids with up to $5-8 \%$ of the total components. Sparry calcite also occurs in the space between the bioclasts, but it is not abundant (Fig. $6 \mathrm{~g}, \mathrm{~h}$ ).

Ripple bedding and parallel lamination are common characteristics at the top of tempestites (Flügel, 2004). These sedimentary structures were identified in the $\mathrm{GSB}_{1}$ and $\mathrm{GSB}_{3}$ (Fig. 6g, h). Ripple bedding occurs in the mudstone at the uppermost part of the $\mathrm{GSB}_{3}$ that is composed of grainstone (Fig. $6 \mathrm{~g})$. It is represented by ripple boundaries between different compositions, including more micrite, micrite and sparry calcite, and more sparry calcite (Fig. 6g). Parallel lamination is present in the mudstone at the uppermost part of the $\mathrm{GSB}_{1}$, comprised of wackestone and packstone (Fig. 6h).

\section{Discussion}

\subsection{Mechanism of the shell bed formation}

Mechanisms of shell accumulations in sedimentary rocks have been shown by a number of workers who have proposed diverse origins (Kidwell et al., 1986), including biologic origin (e.g. Kidwell, 1982), sedimentologic origin (e.g. storm surges (Aigner, 1979, 1985), currents (Futterer, 1978; Wilson, 1982), relative sealevel changes (Dattilo et al., 2012) and sedimentation changes (Kidwell, 1985)) and diagenesis (e.g. Wanless, 1979). In this study, multiple lines of evidence suggest that the accumulation of shells in Gigantoproductus shell beds is related to winnowing and transporting driven by storm surges, which is the principle agent of shell accumulation (Aigner, 1985; Flügel, 2004). First, the taphonomy of Gigantoproductus shells is usually characterized by disarticulation, convex-up and high fragmentation (Figs 3, 5 ), which are obvious characteristics in storm shell beds (Jeffery \& Aigner, 1982; McFarland et al., 1999; Butts, 2005; Jin et al., 2013). Second, the occurrences of sedimentary structures of tempestites in the shell beds, including sharp and erosional base, internal erosional surface and uppermost parallel lamination and ripple bedding (Fig. 6), also indicate that they were formed under strong hydrodynamic energy triggered by storms. Third, different and distinct sedimentary facies were developed in the shell beds, which are one distinct feature of tempestites and absent in the shell beds formed by relative sea-level changes (Dattilo et al., 2012). At the base of the Gandongzi section, articulated and convexdown shells with much micrite, low fragmentation and parallel lamination in the mudstone of its uppermost part dominate the $\mathrm{GSB}_{1}$, suggesting that it is a distal tempestite (Aigner, 1985; Flügel, 2004) (Figs 4a, 5a, 6h). In the upper Gandongzi section, the $\mathrm{GSB}_{3}$ is characterized by high-breakage shells in grainstone and ripple bedding in the mudstone at the uppermost part, implying it is a proximal tempestite (Aigner, 1985; Flügel, 2004) (Figs 4c, 5c, d, 6f, g). In the Yashui and Duanshan sections, the $\mathrm{YSB}_{2}$ and $\mathrm{DSB}_{1}$ are composed of disarticulated and convex-up shells in packstones, indicating they occur between the proximal and distal tempestites (Figs 4b, 5b, 6d, e). Furthermore, during the Viséan to Serpukhovian, the epicontinental sea of South China was surrounded by Yangtze Old Land from north and west and Cathaysia Old Land in the east (Fig. 1c). Such a great bay setting is also suitable for the development of tempestites, which is similar to the Silurian case in northern Guizhou, South China (Li \& Rong, 2007).

\subsection{Palaeoenvironmental implications}

Several storm shell beds have been documented in the United States and southwest England in the Mississippian (Jeffery \& Aigner, 1982; Butts, 2005). In these shell beds, the shells are characterized by different taphonomic types varying from articulated, convexdown and low fragmented shells to disarticulated, convex-up and high-breakage shells, which indicate that they are formed under low and high water energy respectively, driven by storms (Jeffery \& Aigner, 1982; Butts, 2005).

Similar to the other Mississippian storm shell beds, the late Viséan to Serpukhovian Gigantoproductus shell beds in South China also have different shell types in various sedimentary facies, implying different burial environments (Figs 4-6). At the base of the Gandongzi section, the $\mathrm{GSB}_{1}$ includes mostly articulated and convex-down shells with low fragmentation in wackestone and packstone (Figs 5a, 6b, c), which is similar to the shell bed in the United States with in situ shells deposited in very low energy under the storm wave-base (Butts, 2005). However, the occurrences of disarticulated and fragmented shells with sparry calcite between them in the GSB suggest that it was buried around the storm wave-base (Figs $5 \mathrm{a}, 6 \mathrm{~b}, \mathrm{c}$ ). At the upper Gandongzi section, the $\mathrm{GSB}_{3}$ contains highly fragmented shells in grainstone (Figs 5c, d, 6f), implying they were formed under very strong water energy above the fair-weather wave-base (Dattilo et al., 2012). At the Yashui and Duanshan sections, the $\mathrm{YSB}_{2}$ and $\mathrm{DSB}_{1}$ shell beds are mainly composed of disarticulated and convex-up shells with medium fragmentation in packstones (Figs 5b, 6d, e), indicating a relatively high hydrodynamic energy between the storm wave-base and the fair-weather wave-base (Butts, 2005). From the late Viséan to Serpukhovian, widely glacial deposits developed on the Gondwana continent (Isbell et al., 2003, 2012; Fielding et al., 2008), which are similar to the glacial distribution pattern in the late Ordovician, early Silurian and recent times (Jin et al., 2013). Hence, hurricanes between the polar and tropical areas, which are similar to modern times (Jin et al., 2013) (Fig. 7a), would occur during late Viséan and Serpukhovian, and then induce the formation of the brachiopod storm shell beds in South China.

\subsection{Palaeogeographical implications}

Nowadays, tropical hurricanes are usually absent within $10^{\circ}$ north and south of the equator due to the weak Coriolis force (Jin et al., 2013). In contrast, strong hurricanes or cyclones chiefly occur between latitude $10^{\circ}$ and $30^{\circ}$ on both sides of the equatorial zone (Jin et al., 2013). Consistent with the present day situation, a hurricane-free zone was also constrained within latitude $10^{\circ}$ on each side of the equator in the United States and Greenland during the late Ordovician, where non-amalgamated brachiopod shell beds were developed (Jin et al., 2013). Whereas, hurricane zone was present between latitude $10^{\circ}$ and $30^{\circ}$ on both of the equator in South China and United States during the late Ordovician and early Silurian respectively, with amalgamated shell beds formed (Li \& Rong, 2007; Jin et al., 2013). 


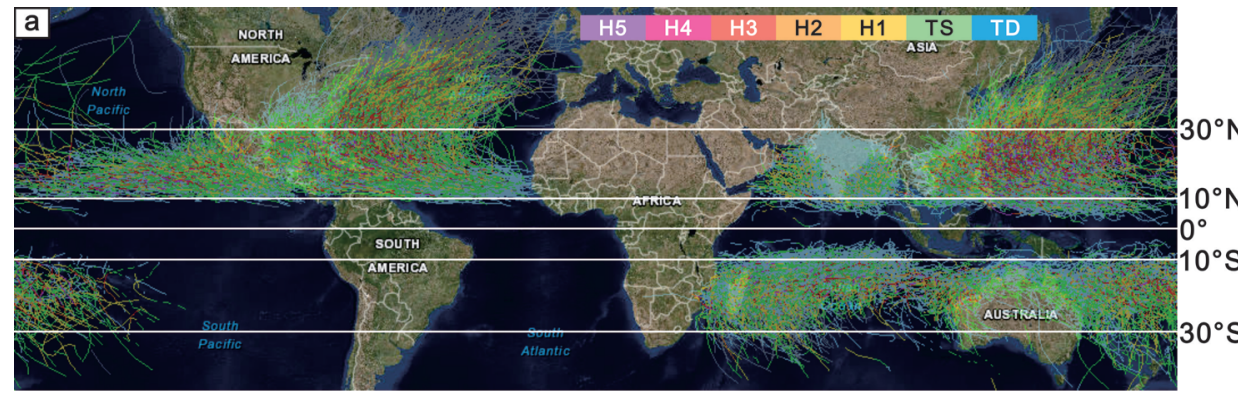

b

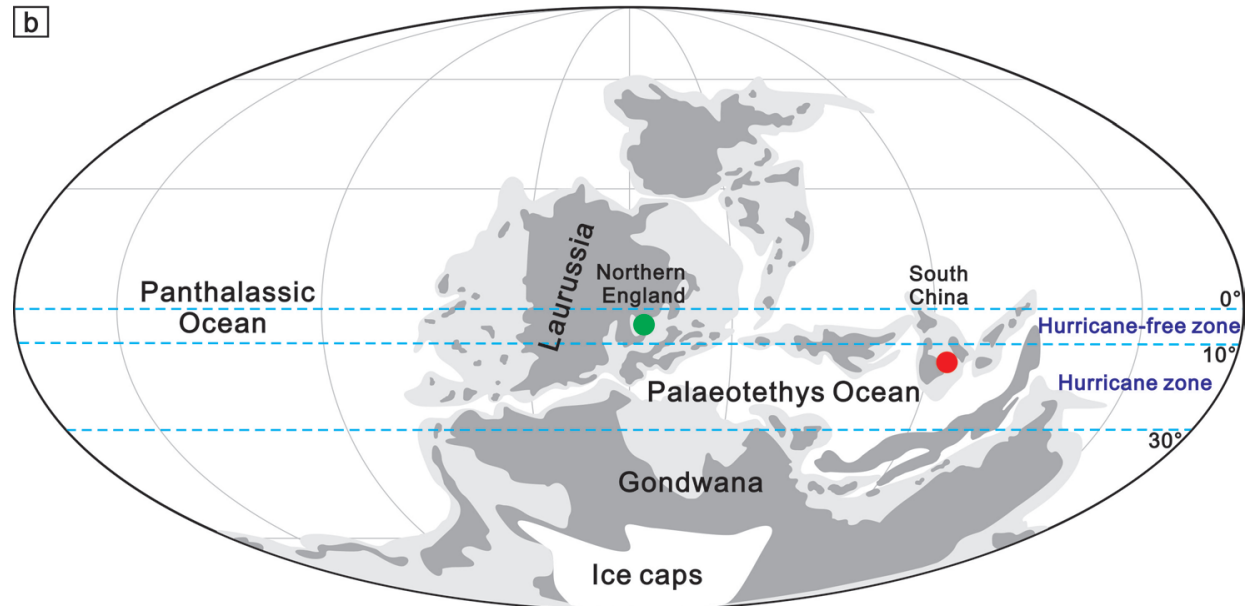

Figure 7. (a) Modern frequency and intensity map of hurricane tracks (from National Oceanic and Atmospheric Administration, 2011). H1-H5: Category 1-5 hurricanes; TS: Tropical storm; TD: Tropical depression. (b) Location of amalgamated shell beds and non-amalgamated shell beds in South China (red solid circle) and northern England (green solid circle) respectively, hurricane and hurricanefree zones and palaeo-latitudes (blue dashed lines) during the late Viséan to Serpukhovian.
On palaeogeographical maps of the Viséan to Serpukhovian times, different positions have been proposed for the SCB (e.g. Scotese and McKerrow, 1990; Golonka et al., 1994; Stampfli \& Borel, 2002; Blakey, 2011). Overall, the SCB was consistently located very near the equator, but its precise location was still unclear. Because the Gondwana continent (south polar) was covered by prominent ice caps from the late Viséan to Serpukhovian (Isbell et al., 2003, 2012; Fielding et al., 2008) (Fig. 7b), it is plausible that this time had similar temperature gradient and hurricane pattern to the modern and late Ordovician periods when ice caps also widely occurred on the south polar area (Jin et al., 2013) (Fig. 7). Thus, it can be assumed that the modern hurricane pattern can be applied to the Mississippian. In Mississippian times, Gigantoproductus shell beds of northern England were characterized by all shells preserved in situ and convex-down (non-amalgamated shell beds), indicating that they occurred in hurricane-free zone within latitude $10^{\circ}$ (Ferguson, 1978) (Fig. 7b). This hypothesis is consistent with the palaeogeographical position of northern England, which is very close to the equator (Scotese \& McKerrow, 1990; Qiao \& Shen, 2015). During the late Viséan to Serpukhovian, in South China, Gigantoproductus shell beds are featured by disturbed and amalgamated shells generated by storms, implying that the SCB was located between latitude $10^{\circ}$ and $30^{\circ}$ where strong hurricanes or cyclones chiefly occurred (Li \& Rong, 2007; Jin et al., 2013) (Fig. 7b). On the first view the position of the SCB in the reconstruction of the aforementioned palaeogeographical studies seem to be reasonable. However, precisely locating the palaeo-latitudes of the SCB and the boundary between hurricane and hurricane-free zones needs the further study of taphonomic types of the storm shell beds located in the same latitudes of the other areas.

\section{Conclusions}

(1) Late Viséan to Serpukhovian storm shell beds of Gigantoproductus are reported for the first time in the Yashui, Duanshan and Gandongzi sections in South China. The shell beds have the characteristics of tempestites, including sharp and erosional base, internal accumulations of amalgamated shells with erosional structure, and parallel lamination and ripple bedding structures in the uppermost part of the shell beds. Four microfacies types are identified in the shell beds, which are wackestone, packstone and grainstone, and mudstone in the uppermost part of the shell beds.
(2) Three taphonomic and sedimentologic types are differentiated for the shell beds. Type A majorly comprises articulated and convex-down shells with low fragmentation in wackestone and packstone, which are developed in distal tempestites under weak hydrodynamic energy around the storm wave-base. Type B is dominated by disarticulated and convex-up shells with medium fragmentation in packstone that are present between proximal and distal tempestites in medium water energy between the storm wavebase and fair-weather wave-base. Type C mainly consists of highly fragmented shells in grainstone, formed in proximal tempestites with strong water energy above the fair-weather wave-base.

(3) Shell accumulation of the shell beds is caused by winnowing and transporting driven by storm-induced bottom flows, evidenced from the amalgamated shells, basal and internal erosional structures, uppermost parallel lamination and ripple bedding structures, and development of proximal and distal tempestites.

(4) During the late Viséan to Serpukhovian, the occurrences of storm shell beds in South China reflect that the South China Block was located in hurricane zone between latitude $10^{\circ}$ and $30^{\circ}$ during this time. The climatic gradient between equatorial and polar regions should have been important with ice caps on the Gondwana continent.

\section{Acknowledgements}

This manuscript was greatly improved from the comments by Axel Munnecke (Erlangen) and Bernard Mottequin (Brussels). We would like to sincerely thank Prof. Zhuoting Liao of Nanjing Institute of Geology and Paleontology for his help in the fieldwork and identification of brachiopods, Prof. Xianghe $\mathrm{Wu}$ for his identification of foraminifers, and Dr. Jitao Chen for his valuable discussion. This work was financially supported by National Natural Science Foundation of China (grant Nos.: 41290260, 41290262), the Strategic Priority Research Program (B) of the Chinese Academy of Sciences (XDB18030400) and the Ministry of Science and Technology Foundation Project.

\section{References}

Ager, D.V., 1973. The nature of the stratigraphical record. Wiley, New York, $114 \mathrm{p}$.

Aigner, T., 1979. Schill-Tempestite im Oberen Muschelkalk (Trias, SWDeutschland). Neues Jahrbuch für Geologie und PaläontologieAbhandlungen, 157, 326-343. 
Aigner, T., 1985. Storm depositional systems: dynamic stratigraphy in modern and ancient shallow marine sequences. Springer, Berlin, Lecture Notes in Earth Sciences 3, 174 p.

Blakey, R., 2011. Global Paleogeography. http://jan.ucc.nau.edu/ rcb7/ globaltext2.html (accessed 13/06/2015).

Boyer, D.L., Bottjer, D.J. \& Droser, M.L., 2004. Ecological signature of Lower Triassic shell beds of the western United States. Palaios, 19, 372-380.

Butts, S.H., 2005. Latest Chesterian (Carboniferous) initiation of Gondwanan glaciation recorded in facies stacking patterns and brachiopod paleocommunities of the Antler foreland basin, Idaho. Palaeogeography, Palaeoclimatology, Palaeoecology, 223, 275-289.

Chen, J., Chen, Z.Q. \& Tong, J.N., 2013. Palaeoecology and taphonomy of two brachiopod shell beds from the Anisian (Middle Triassic) of Guizhou, Southwest China: Recovery of benthic communities from the end-Permian mass extinction. Global and Planetary Change, 73 , 149-160.

Chen, J.T., Montañez, I.P., Qi, Y.P., Wang, X.D., Wang, Q.L., Lin, W., 2016. Coupled sedimentary and $\delta^{13} \mathrm{C}$ records of late Mississippian platform-to-slope successions from South China: Insight into $\delta^{13} \mathrm{C}$ chemostratigraphy. Palaeogeography, Palaeoclimatology, Palaeoecology, 448, 162-178.

Dattilo, B.F., Brett, C.E. \& Schramm, T.J., 2012. Tempestites in a teapot? Condensation-generated shell beds in the Upper Ordovician, Cincinnati Arch, USA. Palaeogeography, Palaeoclimatology, Palaeoecology, 367-368, 44-62.

Davis, E.B., 1999. Tempestite paleostratigraphy of the Martinsburg Fm. (Ordovician), Clinch Mt., TN. University of Tennessee Honors Thesis Projects, unpublished, $73 \mathrm{p}$.

Dunham, R.J., 1962. Classification of carbonate rocks according to depositional texture. In Ham, W.E. (ed.). Classification of carbonate rocks. American Association of Petroleum Geologists, Tulsa, Memoir $1,108-122$

Einsele, G. \& Seilacher, A., 1982. Cyclic and event stratification Springer, Berlin, $536 \mathrm{p}$.

Embry, A.F. \& Klovan, J.E., 1971. A late Devonian reef tract on northeastern Banks Island, N.W.T. Bulletin of Canadian Petroleum Geology, 19, 730-781.

Fang, S.X. \& Hou, F.H., 1986. The Carboniferous sedimentary environments and the bryozoan-coral patch reef of the Datang age of the Langping carbonate platform in Tianlin County, Guangxi province. Acta Sedimentologica Sinica, 4 (3), 30-42. [In Chinese with English abstract]

Feng, Z.Z., Yang, Y.Q. \& Bao, Z.D., 1998. Lithofacies paleogeography of the Carboniferous in South China. Journal of Palaeogeography, 1, 75-86. [In Chinese with English abstract].

Ferguson, J., 1978. Some aspects of the ecology and growth of the Carboniferous Gigantoproductids. Proceedings of the Yorkshire Geological Society, 42, 41-54.

Flügel, E., 2004. Microfacies of carbonate rocks. Springer, Berlin, 976 p.

Fielding, C.R., Frank, T.D., Birgenheier, L.P., Rygel, M.C., Jones, A.T. \& Roberts, J., 2008. Stratigraphic imprint of the Late Palaeozoic Ice Age in eastern Australia: a record of alternating glacial and nonglacial climate regime. Journal of the Geological Society, 165, 129-140.

Fürsich, F.T., 1982. Rhythmic bedding and shell bed formation in the Upper Jurassic of east Greenland. In Einsele, G. \& Seilacher, A. (eds). Cyclic and Event Stratification. Springer, Berlin, 208-222.

Fürsich, F.T. \& Kauffman, E.G., 1984. Palaeoecology of marginal marine sedimentary cycles in the Albian Bear River Formation of southwestern Wyoming. Palaeontology, 27, 501-536.

Futterer, E., 1978. Studien über die Einregelung, Anlagerung und Einbettung biogener Hartteile im Strömungskanal. Neues Jahrbuch für Geologie und Paläontologie-Abhandlungen, 156, 87-131.

Golonka, J., Ross, M.I. \& Scotese, C.R., 1994. Phanerozoic paleogeographic and paleoclimatic modeling maps. In Embry, A.F. Beauchamp, B. \& Glass, D.J. (eds). Pangea: Global environments and resources. Canadian Society of Petroleum Geologists, Calgary, Memoir 17, 1-47.

Groves, J.R., Wang, Y., Qi, Y.P., Richards, B.C., Ueno, K. \& Wang, X.D., 2012. Foraminiferal biostratigraphy of the Viséan-Serpukhovian (Mississippian) boundary interval at slope and platform sections in southern Guizhou (South China). Journal of Paleontology, 86, 753774.

Hance, L., Hou, H.F. \& Vachard, D., 2011. Upper Famennian to Viséan Foraminifers and some carbonate Microproblematica from South China - Hunan, Guangxi and Guizhou. Geological Publishing House, Beijing, $359 \mathrm{p}$.
Isbell, J.L., Miller, M.F., Wolfe, K.L. \& Lenaker, P.A., 2003. Timing of late Paleozoic glaciation in Gondwana: Was glaciation responsible for the development of northern hemisphere cyclothems? In Chan, M.A. \& Archer, A.W. (eds). Extreme depositional environments: Mega end members in geologic time. Boulder, Colorado, Geological Society of America Special Paper 370, 5-24.

Isbell, J.L., Henry, L.C., Gulbranson, E.L., Limarino, C.O., Fraiser, M.L., Koch, Z.J., Ciccioli, P.L. \& Dineen, A.A., 2012. Evaluations of glacial paradoxes during the late Paleozoic Ice Age using the concept of the equilibrium line altitude (ELA) as a control on glaciations. Gondwana Research, 22, 1-19.

Jeffery, D. \& Aigner, T., 1982. Storm sedimentation in the Carboniferous limestones near Weston-Super-Mare (Dinantian, SW-England). In Einsele, G. \& Seilacher, A. (eds). Cyclic and Event Stratification. Springer, Berlin, 240-247.

Jiao, D.Q., Ma, Y.S., Deng, J., Meng, Q.F. \& Li, D.H., 2003. The sequencestratigraphic framework and the evolution of paleogeography for Carboniferous of the Guizhou and Guangxi areas. Geoscience, 17, 294-302. [In Chinese with English abstract].

Jin, J., 2008. Environmental control on temporal and spatial differentiation of Early Silurian pentameride brachiopod communities, Anticosti Island, eastern Canada. Canadian Journal of Earth Sciences, 45, 159187.

Jin, J., Harper, D.A.T., Cocks, L.R.M., McCausland, P.J.A., Rasmussen, C.M.Ø. \& Sheehan, P.M., 2013. Precisely locating the Ordovician equator in Laurentia. Geology, 41, 107-110.

Johnson, M.E., 1989. Tempestites recorded as variable Pentamerus Layers in the Lower Silurian of Southern Norway. Journal of Paleontology, $63,195-205$.

Kidwell, S.M., 1982. Time scales of fossil accumulation: patterns from Miocene benthic assemblages. Third North American Paleontological Convention, Proceedings, Montreal, 1, 295-300.

Kidwell, S.M., 1985. Palaeobiological and sedimentological implications of fossil concentrations. Nature, 318, 457-460.

Kidwell, S.M., Fürsich, F.T. \& Aigner, T., 1986. Conceptual framework for the analysis and classification of fossil concentrations. Palaios, $1,228-238$.

Kidwell, S.M. \& Holland, S.M., 1991. Field description of coarse bioclastic fabrics. Palaios, 6, 426-434

Lehman, D. \& Pope, J.K., 1989. Upper Ordovician tempestites from Swatara Gap, Pennsylvania: Depositional processes affecting the sediments and paleoecology of the fossil faunas. Palaios, 4, 553-564.

Li, Y. \& Rong, J.Y., 2007. Shell concentrations of Early Silurian virgianid brachiopods in northern Guizhou: Temporal and spatial distribution and tempestite formation. Chinese Science Bulletin, 52, 1680-1691.

Lin, W., Wang, X.D., Poty, E., Aretz, M., 2012. Late Viséan to Early Serpukhovian Rugose Corals from the Yashui Section, Guizhou, South China. In Denayer, J., Aretz, M. \& Poty E. (eds). Proceedings of the 11th International Symposium on Fossil Cnidaria and Porifera, Liège, Belgium, 2011. Geologica Belgica, 15, 329-339.

Liu, B.J., Zhang, J.Q. \& Xu, X.S., 1986. On the calcareous tempestites in the Lower Permian of Silong, Xinwen, Sichuan. Acta Geologica Sinica, 1, 55-67. [In Chinese with English abstract].

McFarland, S., Westrop, S.R. \& Cheel, R.J., 1999. Allogenic versus autogenic processes in the genesis of Middle Ordovician brachiopodrich shell beds, Verulam Formation, Ontario. Palaios, 14, 282-287.

National Oceanic and Atmospheric Administration, 2011. Historical hurricane tracks. http://www.csc.noaa.gov/hurricanes/\# (accessed 03/12/2015).

Poty, E., Devuyst, F.-X. \& Hance, L., 2006. Upper Devonian and Mississippian foraminiferal and rugose coral zonations of Belgium and northern France: a tool for Eurasian correlations. Geological Magzine, 143, 829-857.

Prentice, J.E., 1950. The genus Gigantella Sarycheva. Geological Magazine, 87, 436-438

Qiao, L. \& Shen, S.Z., 2014. Global paleobiogeography of brachiopods during the Mississippian-Response to the global tectonic reconfiguration, ocean circulation, and climate changes. Gondwana Research, 26, 1173-1185.

Qiao, L. \& Shen, S.Z., 2015. A global review of the Late Mississippian (Carboniferous) Gigantoproductus (Brachiopoda) faunas and their paleogeographical, paleoecological, and paleoclimatic implications. Palaeogeography, Palaeoclimatology, Palaeoecology, 420, 128-137.

Scotese, C.R. \& McKerrow, W.S., 1990. Revised World maps and introduction. In McKerrow W.S. \& Scotese R.C. (eds). Palaeozoic palaeogeography and biogeography. Geological Society, London, Memoir 12,1-21. 
Simões, M.G. \& Kowalewski, M., 1998. Shell beds as paleoecological puzzles: a case study from the Upper Permian of the Paraná Basin, Brazil. Facies, 38, 175-196.

Stampfli, G.M. \& Borel, G.D., 2002. A plate tectonic model for the Paleozoic and Mesozoic constrained by dynamic plate boundaries and restored synthetic oceanic isochrons. Earth and Planetary Science Letters, 196, 17-33.

Tucker, M.E. \& Wright, V.P., 1990. Carbonate sedimentology. Blackwell scientific, London, $482 \mathrm{p}$.

Wang, W.J., 2011. The foraminiferal fauna across the Mid-Carboniferous boundary in Southern Guizhou, South China. Master Thesis, Graduate University of Chinese Academy of Sciences, unpublished, 121 p. [In Chinese with English abstract].

Wang, X.D. \& Jin, Y.G., 2000. An outline of Carboniferous chronostratigraphy. Journal of Stratigraphy, 24, 90-98. [In Chinese with English abstract].

Wang, X.D., Qie, W.K., Sheng, Q.Y., Qi, Y.P., Wang, Y., Liao, Z.T., Shen, S.Z. \& Ueno, K., 2013. Carboniferous and Lower Permian sedimentological cycles and biotic events of South China. In Gąsiewicz A. \& Słowakiewicz M. (eds). Palaeozoic climate cycles: their evolutionary and sedimentological impact. Geological Society, London, Special Publication 376, 33-46.

Wanless, H.R., 1979. Limestone response to stress: Pressure solution and dolomitization. Journal of Sedimentary Research, 59, 437-462.

Wilson, M.A., 1982. Origin of brachiopod-bryozoan assemblages in an Upper Carboniferous limestone: importance of physical and ecological controls. Lethaia, 15, 263-273.

Yao, L., Qie, W.K., Luo, G.M., Liu, J.S., Algeo, T.J., Bai, X., Yang, B. \& Wang, X.D., 2015. The TICE event: Perturbation of carbonnitrogen cycles during the mid-Tournaisian (Early Carboniferous) greenhouse-icehouse transition. Chemical Geology, 401, 1-14.

Yao, L., Wang, X.D., Lin, W., Li, Y., Kershaw, S. \& Qie, W.K., 2016. Middle Viséan (Mississippian) coral biostrome in central Guizhou, southwestern China and its palaeoclimatological implications. Palaeogeography, Palaeoclimatology, Palaeoecology, 448, 179-194.

Zhang, L.J., 2013. Lower Devonian tempestites in western Yangtze, South China: insight from Zoophycos ichnofabrics. Geological Journal, 49, 177-187.

Zhang, T.S., Hou, F.H., Gao, W.D. \& Lan, G.Z., 1993. Tempestites and the environmental palaeoecological significance of Early Silurian, NW Sichuan area. Acta Sedimentologica Sinica, 11 (2), 66-74. [In Chinese with English abstract]. 